ISSN: 2302-8556

E-Jurnal Akuntansi Universitas Udayana

Vol.22.1. Januari (2018): $\mathbf{3 0 - 5 0}$

DOI: https://doi.org/10.24843/EJA.2018.v22.i01.p02

\title{
Budaya Organisasi Sebagai Pemoderasi Pengaruh Partisipasi Penganggaran Pada Kinerja Anggaran Pemerintah Daerah Kabupaten Badung
}

\author{
A. A. Ayu Octa Triani ${ }^{1}$ \\ I Ketut Sujana ${ }^{2}$ \\ ${ }^{1}$ Fakultas Ekonomi dan Bisnis Universitas Udayana (Unud), Bali, Indonesia \\ e-mail: ayuoctatriani@ymail.com/ Telp : 082247813494 \\ ${ }^{2}$ Fakultas Ekonomi dan Bisnis Universitas Udayana (Unud), Bali, Indonesia
}

\begin{abstract}
ABSTRAK
Penelitian ini bertujuan untuk mendapatkan bukti empiris budaya organisasi sebagai pemoderasi pengaruh partisipasi penganggaran pada kinerja anggaran pemerintah daerah Kabupaten Badung. Populasi yang digunakan dalam penelitian ini adalah 15 dinas di Satuan Kerja Pemerintah Daerah Kabupaten Badung. Sampel dalam penelitian ini ditentukan dengan metode purposive sampling. Data dikumpulkan dengan menggunakan metode survey. Teknik analisis data yang digunakan adalah Moderated Regression Analysis (MRA). Hasil penelitian menunjukkan bahwa partisipasi penganggaran berpengaruh pada kinerja anggaran pemerintah daerah Kabupaten Badung. Hasil pengujian moderasi menunjukkan bahwa budaya organisasi mampu memoderasi pengaruh partisipasi penganggaran pada kinerja anggaran pemerintah daerah Kabupaten Badung, yang artinya budaya organisasi memperkuat pengaruh partisipasi penganggaran pada kinerja anggaran pemerintah daerah Kabupaten Badung.
\end{abstract}

Kata kunci: Partisipasi penganggaran, kinerja anggaran, budaya organisasi

\begin{abstract}
This study aims to obtain empirical evidence of organizational culture as a moderator of the influence of budgetary participation on the performance of local government budget of Badung regency. The population used in this research is 15 departments in the Local Government Work Unit of Badung Regency. The sample in this research is determined by purposive sampling method. Data were collected using survey method. Data analysis technique used is Moderated Regression Analysis (MRA). The results showed that budgetary participation had an effect on the local government budget performance of Badung Regency. The results of moderation testing indicate that organizational culture is able to moderate the influence of budgetary participation on local government budget performance of Badung Regency, which means organizational culture strengthens the influence of budgetary participation in local government budget performance of Badung regency.

Keywords: Budgetary participation, budget performance, organizational culturesize, corporate social responsibility
\end{abstract}




\section{PENDAHULUAN}

Indonesia menganut asas desentralisasi yang memberikan kebebasan dan keleluasaan kepada pemerintah daerah dalam menyelenggarakan pemerintahan melalui Otonomi Daerah. Berdasarkan Undang-Undang Republik Indonesia Nomor 32 Tahun 2004 Tentang Pemerintahan Daerah dan Peraturan Pemerintah Republik Indonesia Nomor 38 Tahun 2007 tentang Pembagian Urusan Pemerintahan antara Pemerintah, Pemerintah Daerah Propinsi, dan Pemerintah Daerah Kabupaten/Kota, Pemerintah Daerah dituntut untuk lebih memberikan pelayanan kepada masyarakat dengan menerapkan asas-asas pelayanan publik yang didalamnya meliputi: transparansi, akuntabilitas, partisipatif, kesamaan hak, keseimbangan hak, dan kewajiban.

Setiap organisasi pemerintahan, dalam menjalankan tugasnya wajib untuk mempunyai perencanaan yang telah disusun dalam bentuk anggaran. Anggaran yang dibuat oleh pemerintah daerah dapat menjadi cermin seberapa fungsi pemerintah dalam melaksanakan berbagai urusan pemerintahan yang menjadi tanggung jawabnya dan faktor-faktor apa saja yang dapat mempengaruhinya. Anggaran dalam perubahan paradigma pada daerah kini dilakukan untuk mendapatkan anggaran yang akan mencerminkan kepentingan serta sesuai dengan harapan yang diinginkan publik dalam pengelolaan keuangan daerah secara ekonomis, efisien, dan efektif.

Anggaran daerah merupakan rencana keuangan yang menjadi dasar dalam pelaksanaan pelayanan publik. Di Indonesia, dokumen anggaran daerah disebut Anggaran Pendapatan dan Belanja Daerah (APBD), baik untuk pemerintah provinsi, kabupaten, atau kota. Sebelum penyusunan APBD dilakukan, maka terlebih dahulu 
ISSN: 2302-8556

E-Jurnal Akuntansi Universitas Udayana

Vol.22.1. Januari (2018): 30-50

harus dibuat kesepakatan antara eksekutif dan legislatif tentang arah dan kebijakan umum, dan prioritas anggaran, yang akan menjadi pedoman untuk penyusunan anggaran pendapatan dan anggaran belanja.

Peran penting anggaran dalam organisasi sektor publik berasal dari kegunaannya dalam menentukan estimasi pendapatan atau jumlah tagihan atas jasa yang diberikan. Peran anggaran dalam siklus perencanaan dan pengendalian manajemen lebih dari sekedar dua hal tersebut karena anggaran memiliki keterikatan antara perencanaan dan pengendalian. Peranan anggaran dalam perencanaan dicapai dengan menyatakan dalam nilai uang besarnya input yang diperlukan untuk melaksanakan aktivitas yang direncanakan dalam periode anggaran. Sementara itu, peranan anggaran dalam pengendalian dapat dicapai dengam mempersiapkan anggaran dengan cara yang dapat menunjukkan input dan sumber daya yang telah dialokasikan kepada individu atau departemen sehingga memungkinkan mereka untuk melakukan tugas yang dibebankan kepada mereka.

Anggaran digunakan selain untuk mengukur kinerja juga dapat digunakan untuk mengontrol dan mempengaruhi perilaku pihak-pihak terkait dengan penetapan dan pelaksanaan anggaran. (Mardiasmo, 2005) mendefinisikan anggaran sebagai pernyataan mengenai estimasi kinerja yang hendak dicapai selama periode tertentu yang dinyatakan dalam ukuran finansial, dan penganggaran merupakan proses atau metode untuk mempersiapkan suatu anggaran. Sementara itu, menurut Sebastian (2006) anggaran merupakan paket pernyataan perkiraan penerimaan dan pengeluaran yang diharapkan akan terjadi dalam satu atau beberapa periode mendatang. 
A. A. Ayu Octa Triani dan I Putu Sujana. Budaya ...

Penganggaran dalam sektor publik terkait dengan proses penentuan jumlah alokasi dana untuk setiap program dan aktivitas dalam satuan moneter. Proses penganggaran sektor publik dimulai ketika perumusan strategi dan perencanaan strategik telah selesai dilakukan. Tahap penganggaran menjadi sangat penting karena anggaran yang tidak efektif dan tidak berorientasi pada kinerja akan dapat menggagalkan perencanaan yang sudah disusun. Anggaran merupakan managerial plan for action untuk memfasilitasi tercapainya tujuan organisasi.

Proses penganggaran merupakan sebuah proses penting yang seringkali menjadi perhatian tersendiri bagi sebuah organisasi sektor publik terutama pemerintah. Proses penyusunan anggaran pada pemerintahan harus memfokuskan tujuannya untuk mensejahterakan masyarakat. Untuk itulah dibutuhkan informasi yang sangat akurat dalam penyusunan anggaran pemerintah daerah. Dengan adanya tuntutan untuk pemerintah daerah agar turut serta berpartisipasi dalam proses penyusunan anggaran, maka diperlukannya komunikasi antara atasan dan bawahan.

Penganggaran dapat dilakukan dengan pendekatan top-down dan bottom-up (Chandra, 1992. dalam Rosidi, 2000). Pendekatan top-down atau penganggaran otoritatif adalah dimana manajemen puncak menyusun anggaran untuk organisasi secara keseluruhan, termasuk operasi level bawah. Sedangkan pendekatan bottom-up atau partisipasi memungkinkan terjadinya negosiasi antara para manajer untuk mencapai tujuan organisasi.

Partisipasi dalam pengertian yang luas, merupakan inti dari proses demokratis dan oleh karena itu tidaklah alamiah jika diterapkan dalam struktur organisasi yang 
ISSN: 2302-8556

E-Jurnal Akuntansi Universitas Udayana

Vol.22.1. Januari (2018): 30-50

otoriter. Brownell dalam Coryanta (2004) menyatakan bahwa partisipasi penganggaran adalah tingkat keterlibatan dan pengaruh seseorang dalam proses penganggaran. Salah satu manfaat dari partisipasi adalah bahwa partisipan menjadi terlibat secara emosi bukan hanya secara tugas dalam pekerjaan mereka. Partisipasi juga dapat meningkatkan moral dan mendorong inisiatif yang lebih besar pada semua tingkatan manajemen dan dapat meningkatkan rasa kesatuan kelompok. Partisipasi dapat menunjukkan pengaruh yang baik terhadap sikap dari pegawai, sehingga dapat memberikan peningkatan kuantitas serta kualitas produksi, dan meningkatkan kerjasama diantara manajer (Sardjito dan Muthaher, 2007). Mardiasmo (2002) menyatakan bahwa, partisipasi penganggaran sebagai salah satu kekonsistensian seseorang dalam proses penganggaran.

Adanya tuntutan untuk pemerintah daerah agar turut serta berpartisipasi dalam proses penyusunan anggaran, maka diperlukannya komunikasi antara atasan dengan bawahan. Kinerja aparat pemerintah daerah yang belum maksimal dalam penyusunan anggaran biasanya disebabkan oleh terbatasnya personel, baik secara kualitas atau kuantitas di pemerintah daerah. Mangkunegara (2005) menyatakan bahwa kinerja pegawai adalah hasil kerja secara kualitas, kuantitas dan ketepatan waktu yang dicapai oleh seorang karyawan dalam melaksanakan tugasnya sesuai dengan tanggung jawab yang diberikan.

Pengukuran kinerja adalah instrumen yang digunakan untuk menilai hasil akhir pelaksanaan kegiatan terhadap target dan tujuan kegiatan yang telah ditetapkan sebelumnya. Terdapat enam tujuan utama penilaian kinerja di sektor publik 
(Mahmudi, 2007) antara lain, mengetahui tingkat ketercapaian tujuan organisasi, menyediakan sarana pembelajaran pegawai, memperbaiki kinerja periode berikutnya, memberikan pertimbangan yang sistematik dalam pembuatan keputusan, pemberian penghargaan, dan hukuman, memotivasi pegawai, dan menciptakan akuntabilitas publik.

Dalam rangka mewujudkan budaya organisasi yang cocok diterapkan pada sebuah organisasi, maka diperlukan adanya dukungan dan partisipasi dari semua anggota yang ada dalam lingkup organisasi tersebut. Para karyawan membentuk persepsi keseluruhan berdasarkan karakteristik budaya organisasi yang antara lain meliputi inovasi, kemantapan, kepedulian, orientasi hasil, perilaku pemimpin, orientasi tim, karakteristik tersebut terdapat dalam sebuah organisasi atau perusahaan mereka. Persepsi karyawan mengenai kenyataan terhadap budaya organisasinya menjadi dasar karyawan berperilaku. Dari persepsi tersebut memunculkan suatu tanggapan berupa dukungan pada karakrteristik organisasi yang selanjutnya mempengaruhi kinerja karyawan. Indriantoro (2000) menemukan pengaruh dimensi budaya terhadap efektivitas partisipasi dalam penyusunan anggaran dalam peningkatan kinerja manajerial. Penelitian oleh Mustikawati (1999) juga menunjukkan bahwa interaksi partisipasi dalam penyusunan anggaran dengan budaya paternalistik mempunyai pengaruh yang signifikan terhadap peningkatan kinerja manajerial.

Kabupaten Badung merupakan salah satu kabupaten di provinsi Bali yang mempunyai Pendapatan Asli Daerah (PAD) yang cukup tinggi. Pada tahun 2014, 
ISSN: 2302-8556

E-Jurnal Akuntansi Universitas Udayana

Vol.22.1. Januari (2018): 30-50

Kabupaten Badung menyumbang 75,9\% dari seluruh PAD Provinsi Bali. Dalam rangka optimalisasi potensi pendapatan daerah, maka kebijakan yang ditempuh Pemerintah Daerah Kabupaten Badung sesuai dengan rencana pembangunan jangka menengah daerah yakni sumber-sumber yang berasal dari pajak dan retribusi daerah serta lain-lain pendapatan tetap dipertahankan serta diperluas dan diintensifkan pemungutannya. Perkembangan APBD tahun anggaran 2009-2014 di Kabupaten Badung dapat dilihat pada Tabel 1 berikut ini :

Tabel 1.1

Realisasi Pendapatan dan Belanja Daerah Kabupaten Badung Tahun Anggaran 2009 - 2014

\begin{tabular}{llllccc}
\hline Tahun & $\begin{array}{c}\text { Anggaran } \\
\text { Pendapatan } \\
\text { Daerah } \\
\text { (jutaan Rp) }\end{array}$ & $\begin{array}{c}\text { Realisasi } \\
\text { Pendapatan } \\
\text { Daerah } \\
\text { (jutaan Rp) }\end{array}$ & $\begin{array}{c}\mathbf{( \% )} \\
\text { Anggaran } \\
\text { Belanja } \\
\text { Daerah (jutaan } \\
\text { Rp) }\end{array}$ & $\begin{array}{c}\text { Realisasi } \\
\text { Belanja } \\
\text { Daerah (jutaan } \\
\text { Rp) }\end{array}$ & $(\%)$ \\
\hline 2009 & $1.311 .050,4$ & $1.404 .323,6$ & 107 & $1.667 .379,5$ & $1.429 .409,0$ & 86 \\
2010 & $1.352 .639,4$ & $1.387 .111,5$ & 103 & $1.570 .199,1$ & $1.319 .058,4$ & 84 \\
2011 & $1.541 .930,6$ & $1.850 .767,4$ & 120 & $1.812 .280,4$ & $1.445 .206,8$ & 80 \\
2012 & $2.410 .693,9$ & $2.620 .854,1$ & 108 & $2.671 .642,8$ & $2.334 .080,3$ & 87 \\
2013 & $2.718 .030,3$ & $2.954 .662,9$ & 109 & $3.027 .775,9$ & $2.755 .459,7$ & 91 \\
2014 & $3.155 .737,1$ & $3.459 .986,0$ & 110 & $3.614 .006,5$ & $3.276 .164,1$ & 91 \\
\hline
\end{tabular}

Sumber: Badan Pengelola Keuangan dan Aset Daerah Kabupaten Badung (data diolah 2015).

Penelitian yang dilakukan oleh Bambang dan Osmad (2007) dalam Sardjito (2007), menujukkan bahwa budaya organisasi memiliki pengaruh signifikan dalam hubungan antara partisipasi penyusunan anggaran terhadap kinerja aparat pemerintah daerah. Budaya organisasi memiliki enam dimensi praktis yang salah satunya adalah employee oriented (berorientasi pada orang). Dimensi tersebut merupakan dimensi yang mempunyai kaitan erat dengan praktik pembuatan keputusan partisipatif, yaitu dimensi praktik yang berorientasikan kepada orang (employee oriented) dan kepada 
pekerjaan (job oriented). Dengan adanya budaya organisasi yang berorientasikan kepada orang, maka partisipasi dalam penyusunan anggaran akan semakin tinggi yang juga berdampak terhadap kinerja yang semakin meningkat (Bambang, 1998).

Budaya organisasi menjadi dasar untuk perasaan saling memahami yang dimiliki aparat pemerintah daerah mengenai instansi mereka, bagaimana segala sesuatu dikerjakan berdasarkan pengertian bersama tersebut dan cara-cara aparat pemerintah daerah seharusnya bersikap. Pihak instansi juga harus dapat memadukan karakter-karakter budaya organisasi yang ada untuk menciptakan suatu instansi dengan keanekaragaman tinggi dan pada akhirnya nanti akan dapat meningkatkan kinerja anggaran pemerintah daerah. Maka dari itu penelitian ini mengidentifikasi secara menyeluruh bagaimana budaya organisasi sebagai pemoderasi pengaruh partisipasi penganggaran pada kinerja anggaran pemerintah daerah Kabupaten Badung.

Anggaran yang telah ditetapkan berfungsi sebagai perencanaan dan sebagai kriteria kinerja, yaitu anggaran dipakai sebagai suatu sistem pengendalian untuk mengukur kinerja manajerial. Untuk mencegah dampak fungsional atau disfungsionalnya, sikap dan perilaku anggota organisasi dalam penyusunan anggaran perlu melibatkan manajemen pada level yang lebih rendah sehingga anggaran partisipatif dapat dinilai sebagai pendekatan manajerial yang dapat meningkatkan kinerja setiap anggota organisasi sebagai individual karena dengan adanya partisipasi dalam penyusunan anggaran diharapkan setiap individu mampu meningkatkan 
ISSN: 2302-8556

E-Jurnal Akuntansi Universitas Udayana

Vol.22.1. Januari (2018): 30-50

kinerjanya sesuai dengan target yang telah ditentukan (Bambang Sardjito dan Osmad Muthaher, 2007).

Penelitian yang dilakukan oleh (Nor, 2007) menemukan bahwa partisipasi penyusunan anggaran dan kinerja memiliki hubungan yang positif. Partisipasi penganggaran dapat dinilai sebagai pendekatan manajerial yang dapat meningkatkan kinerja setiap anggota organisasi sebagai individual karena dengan adanya partisipasi dalam penganggaran diharapkan setiap individu mampu meningkatkan kinerjanya sesuai dengan target yang telah ditetapkan sebelumnya. Semakin tinggi tingkat partisipasi penganggaran maka semakin tinggi pula kinerja aparat pemerintah daerah.

$\mathrm{H}_{1}$ : Partisipasi penganggaran berpengaruh positif pada kinerja anggaran pemerintah daerah Kabupaten Badung.

Budaya organisasi merupakan nilai-nilai dari keyakinan yang dimiliki para anggota organisasi yang dituangkan dalam bentuk norma-norma perilaku para individu atau kelompok organisasi ditempat individu tersebut bekerja (Hofstede at.al 1990) dalam Sardjito (2007). Holmes dan Marsden (1996) dalam Sardjito (2007) menyatakan bahwa budaya organisasi mempunyai pengaruh terhadap perilaku, cara kerja dan motivasi para manajer dan bawahannya untuk mencapai kinerja organisasi. Penelitian yang dilakukan oleh Soewito dan Sugiyanto (2001) dalam Sardjito (2007) menunjukkan bahwa budaya berpengaruh signifikan terhadap tercapainya kinerja karyawan yang tinggi. Hasil penelitian yang dilakukan oleh Masrukhin dan Waridin (2006) dan Sitty Yuwalliatin (2006) dalam Sardjito (2007) menunjukkan adanya pengaruh positif dari budaya organisasi terhadap kinerja karyawan. Berdasarkan hasil 
penelitian yang berkaitan dengan budaya, ditentukan bahwa dimensi budaya mempunyai pengaruh terhadap penyusunan anggaran dalam meningkatkan kinerja manajerial.

$\mathrm{H}_{2}$ : Budaya organisasi mampu memoderasi pengaruh partisipasi penganggaran terhadap kinerja anggaran pemerintah daerah Kabupaten Badung.

\section{METODE PENELITIAN}

Jenis penelitian yang dilakukan ini merupakan penelitian asosiatif kausal. Penelitian asosiatif kausal adalah penelitian yang memiliki tujuan mengetahui pengaruh variabel bebas dengan variabel terikat. Pendekatan ini menyatakan pengaruh antara variabel independen yaitu pertisipasi penganggaran, pada variabel dependen yaitu kinerja anggaran pemerintah daerah dengan budaya organisasi sebagai variabel moderasi.

Penelitian ini dilakukan di Satuan Kerja Perangkat Daerah (SKPD) Kabupaten Badung. Kabupaten Badung memiliki 15 dinas yang seluruhnya beralamat di Pusat Pemerintahan Kabupaten Badung, Jalan Raya Sempidi, Mengwi, Badung. Objek dalam penelitian ini adalah partisipasi penganggaran dan kinerja anggaran pemerintah daerah Kabupaten Badung. Variabel-variabel dalam penelitian ini terdiri dari variabel bebas $(\mathrm{X})$ yaitu partisipasi penganggaran, variabel terikat $(\mathrm{Y})$ yaitu kinerja anggaran pemerintah daerah dan variabel moderasi yaitu budaya organisasi.

Partisipasi penganggaran adalah tingkat seberapa jauh keterlibatan dan pengaruh individu (manajer) didalam menentukan dan menyusun anggaran yang ada dalam divisi atau bagiannya, baik secara periodik maupun tahunan. Pengukuran kinerja sektor publik adalah sistem yang digunakan untuk membantu para manajer 
ISSN: 2302-8556

E-Jurnal Akuntansi Universitas Udayana

Vol.22.1. Januari (2018): 30-50

publik dalam menilai pencapaian suatu strategi dengan menggunakan alat ukur financial dan non financial, selain itu sistem pengukuran kinerja juga dapat dijadikan sebagai pengendalian organisasi karena di dalam pengukuran kinerja juga ditetapkan reward and punishment system (Wulandari, 2011). Budaya organisasi adalah cara berpikir dari segolongan manusia untuk mencapai tujuan, dalam suatu ruang (tempat) dan waktu. Budaya perusahaan atau organisasi mempunyai pengaruh terhadap perilaku, cara kerja dan motivasi para manajer dan bawahannya untuk mencapai kinerja organisasi.

Penelitian ini menggunakan dua jenis data yaitu data kualitatif dan data kuantitatif. Data kuantitatif dalam penelitian ini adalah hasil jawaban responden dari kuisioner yang dibagikan pada responden. Data kualitatif dalam penelitian ini adalah kuisioner yang dibagikan pada responden. Sumber data dalam penelitian ini terdiri dari data primer dan data sekunder. Data primer yang dimaksudkan dalam penelitian ini diperoleh dari kuesioner yang dibagikan kepada para responden. Kuisioner tersebut dibagikan secara langsung oleh peneliti kepada para aparat SKPD Kabupaten Badung. Data sekunder dalam penelitian ini didapatkan melalui tinjauan kepustakaan dan mengakses website yang berkaitan dengan penelitian.

Populasi yang digunakan dalam penelitian ini yaitu seluruh pejabat/pegawai yang terlibat langsung dalam penyusunan anggaran di 15 dinas Satuan Kerja Perangkat Daerah Kabupaten Badung yang berjumlah 120 orang. Penentuan sampel dalam penelitian ini menggunakan metode purposive sampling, yaitu penentuan sampel dari populasi yang ada berdasarkan kriteria. Berdasarkan metode tersebut 
maka kriteria penentuan sampel yang digunakan dalam penelitian ini adalah para pihak yang terlibat minimal satu tahun dalam proses penyusunan anggaran.

Analisis deskriptif menggambarkan tentang deskripsi data-data penelitian. Analisis ini digunakan untuk menggambarkan statistik data penelitian dan demografi responden. Menurut Ghozali (2009:19) statistik deskriptif dapat menjelaskan skala jawaban responden pada setiap variabel yang diukur dari minimum, maksimum ratarata, dan standar deviasi, juga untuk mengetahui demografi responden. Dalam penelitian ini menggunakan kuisioner sebagai salah satu sumber data, sehingga perlu dilakukan uji validitas dan uji reliabilitas untuk menguji kelayakan dan keakuratan dari kuesioner yang diterima. Uji asumsi klasik dilakukan sebelum menguji dan menganalisi data dengan model regresi. Uji asumsi klasik penelitian ini dilakukan dengan melakukan uji normalitas dan uji heteroskedastisitas. Pada penelitian ini, uji autokorelasi tidak dilakukan karena data yang digunakan tidak berbentuk deret waktu, di mana pengukuran semua variabel dilakukan secara serempak pada saat yang bersamaan.

Salah satu cara yang dapat dilakukan untuk menguji apakah suatu variabel merupakan variabel moderating yakni dengan menggunakan uji interaksi. Regresi dengan melakukan uji interaksi antarvariabel disebut dengan Moderated Regression Analysis (MRA). MRA merupakan aplikasi khusus regresi berganda linier dimana dalam persamaan regresinya mengandung unsur interaksi. MRA digunakan untuk meneliti pengaruh variabel pemoderasi terhadap partisipasi penganggaran pada kinerja aparat pemerintah daerah. Model ini bertujuan untuk mengetahui apakah 
ISSN: 2302-8556

E-Jurnal Akuntansi Universitas Udayana

Vol.22.1. Januari (2018): 30-50

variabel moderasi mampu mempengaruhi hubungan antara variabel bebas dan terikat, dimana dalam persamaan regresinya mengandung unsur interaksi. Uji MRA di dalam penelitian ini digambarkan dengan persamaan regresi berikut ini:

$\mathrm{Y}=\alpha+\beta 1 . \mathrm{X} 1+\beta 2 . \mathrm{X} 2+\beta 3(\mathrm{X} 1 * \mathrm{X} 2)+\mathrm{e}$

Keterangan:

Y : kinerja anggaran pemerintah daerah

$\alpha \quad$ : konstanta

$\beta 1-\beta 3$ : koefisien

$\mathrm{X}_{1} \quad$ : variabel partisipasi penganggaran

$\mathrm{X}_{2} \quad$ : variabel budaya organisasi

$\mathrm{X}_{1} \cdot \mathrm{X}_{2}$ : interaksi antara partisipasi penganggaran dan kinerja

e $\quad$ : standar error (kekeliruan pengukuran dan pengaruh faktor lain)

Pengujian signifikansi secara simultan menggunakan uji F, dalam penelitian ini uji $\mathrm{F}$ digunakan untuk melihat kelayakan model penelitian. Menurut Ghozali (2012:98) uji statistik F pada dasarnya menunjukkan apakah semua variabel independen atau bebas yang dimasukkan dalam model mempunyai pengaruh secara bersama-sama terhadap variabel dependen atau terikat. Menguji model penelitian ini dilakukan dengan menghitung koefisien determinasi $\left(\mathrm{R}^{2}\right)$ yang pada intinya mengukur seberapa jauh kemampuan model dalam menerangkan variabel dependen. Pengujian hipotesis adalah menggunakan uji statistik t. Uji statistik t pada dasarnya bertujuan untuk mengetahui seberapa jauh pengaruh suatu variabel independen secara individu dalam menerangkan variasi variabel dependen.

\section{HASIL DAN PEMBAHASAN}

Pengujian ini bertujuan untuk menguji hubungan antara pengaruh antara satu variabel independen dengan dependen. Uji ini digunakan untuk mengetahui mengetahui 
pengaruh partisipasi penganggaran $\left(\mathrm{X}_{1}\right)$ yang di moderasi oleh budaya organisasi (X2), pada kinerja anggaran pemerintah daerah (Y) pada Satuan Kerja Perangkat Daerah (SKPD) Kabupaten Badung. Hasil pengujian dapat dilihat dalam tabel 2 berikut ini :

\section{Tabel 2}

Hasil Uji MRA

\begin{tabular}{|c|c|c|c|c|c|}
\hline Variabel Terikat & $\begin{array}{c}\text { Variabel } \\
\text { Bebas }\end{array}$ & $\begin{array}{c}\text { Koefisien } \\
\text { Regresi }\end{array}$ & $\begin{array}{l}\text { Standar } \\
\text { Error }\end{array}$ & t- hitung & Sig. \\
\hline \multirow{3}{*}{$\begin{array}{c}\text { Budaya } \\
\text { Organisasi }\end{array}$} & $\mathrm{X} 1$ & 0.684 & 0.206 & 3.315 & 0.001 \\
\hline & $\mathrm{X} 2$ & 0.797 & 0.245 & 3.249 & 0.002 \\
\hline & X1X2 & 0.050 & 0.013 & 3.718 & 0.000 \\
\hline \multicolumn{2}{|c|}{ Constant $\quad=6,143$} & & -Hitung & $=254,183$ & \\
\hline
\end{tabular}

Sumber: data primer diolah, 2017

Berdasarkan Tabel 2, maka diperoleh hasil sebagai berikut nilai konstanta sebesar 6,143 apabila partisipasi penganggaran $\left(\mathrm{X}_{1}\right)$, dan budaya organisasi $\left(\mathrm{X}_{2}\right)$ sama dengan nol, maka Kinerja annggaran pemerintah daerah (Y) sebesar 6,143. Nilai koefisien regresi partisipasi penganggaran $\left(\mathrm{X}_{1}\right)$ sebesar 0,684, menunjukkan bahwa terdapat pengaruh positif antara variabel partisipasi penganggaran $\left(\mathrm{X}_{1}\right)$ terhadap variabel kinerja anggaran pemerintah daerah (Y) sebesar 0,684. Nilai koefisien regresi budaya organisasi $\left(\mathrm{X}_{2}\right)$ sebesar 0,797 , menunjukkan bahwa terdapat pengaruh positif antara variabel budaya organisasi $\left(\mathrm{X}_{2}\right)$ terhadap variabel kinerja anggaran pemerintah daerah $(\mathrm{Y})$ sebesar 0,797 . Nilai koefisien regresi $\left(\mathrm{X}_{1} \mathrm{X}_{2}\right)$ sebesar 0,050, menunjukkan bahwa dengan adanya X2 maka pengaruh X1 terhadap Y akan semakin diperkuat. 
ISSN: 2302-8556

E-Jurnal Akuntansi Universitas Udayana

Vol.22.1. Januari (2018): 30-50

Berdasarkan tabel 2, dapat disimpulkan bahwa besarnya nilai koefisien determinasi ditunjukkan dengan nilai adjusted $\mathrm{R}$ square $\left(\mathrm{R}^{2}\right)$ adalah 0,865 . Hasil ini berarti bahwa pengaruh variabel partisipasi penganggaran $\left(\mathrm{X}_{1}\right)$, budaya organisasi $\left(\mathrm{X}_{2}\right)$, interaksi $\mathrm{X}_{1} \mathrm{X}_{2}$, terhadap kinerja anggaran pemerintah daerah (Y) sebesar 86,5 persen dan sisanya 13,5 persen dipengaruhi oleh faktor-faktor lain di luar model penelitian. Nilai dari F hitung 254,183 dengan nilai signifikansi 0.000 (kurang dari 0.05) maka disimpulkan bahwa ada pengaruh yang signifikan dari variabel independen terhadap variabel dependen secara simultan (bersama-sama). Sehingga model penelitian katakan layak digunakan sebagai model regresi moderasi.

Berdasarkan hasil yang di sajikan pada Tabel 2 menyatakan bahwa $\beta_{1}=0,684$ dengan tingkat signifikan uji t sebesar 0,001 yang menunjukkan angka lebih kecil daripada taraf nyata dalam penelitian ini yaitu 0,05 . Hal tersebut menunjukkan variabel partisipasi anggaran berpengaruh positif terhadap kinerja anggaran pemerintah daerah Kabupaten Badung. Dengan demikian hipotesis pertama $\left(\mathrm{H}_{1}\right)$ dapat diterima yaitu, partisipasi penganggaran berpengaruh positif pada kinerja anggaran pemerintah daerah Kabupaten Badung. Anggaran yang telah ditetapkan berfungsi sebagai perencanaan dan sebagai kriteria kinerja, yaitu anggaran dipakai sebagai suatu sistem pengendalian untuk mengukur kinerja manajerial. Untuk mencegah dampak fungsional atau disfungsionalnya, sikap dan perilaku anggota organisasi dalam penyusunan anggaran perlu melibatkan manajemen pada level yang lebih rendah sehingga anggaran partisipatif dapat dinilai sebagai pendekatan 
manajerial yang dapat meningkatkan kinerja setiap anggota organisasi sebagai individual karena dengan adanya partisipasi dalam penyusunan anggaran diharapkan setiap individu mampu meningkatkan kinerjanya sesuai dengan target yang telah ditentukan (Sardjito, 2007).

Penelitian yang dilakukan oleh (Nor, 2007) menemukan bahwa partisipasi penyusunan anggaran dan kinerja memiliki hubungan yang positif. Partisipasi penganggaran dapat dinilai sebagai pendekatan manajerial yang dapat meningkatkan kinerja setiap anggota organisasi sebagai individual karena dengan adanya partisipasi dalam penganggaran diharapkan setiap individu mampu meningkatkan kinerjanya sesuai dengan target yang telah ditetapkan sebelumnya. Semakin tinggi tingkat partisipasi penganggaran maka semakin tinggi pula kinerja aparat pemerintah daerah.

Berdasarkan hasil yang disajikan pada Tabel 2 menyatakan bahwa $\beta_{3}=0,050$ dengan tingkat signifikan uji t sebesar 0,000 yang menunjukkan angka lebih kecil daripada taraf nyata dalam penelitian ini yaitu 0,05 . Hal tersebut menunjukkan Budaya organisasi mempengaruhi hubungan antara partisipasi penganggaran dan kinerja anggaran pemerintah daerah Kabupaten Badung. Dengan demikian hipotesis kedua $\left(\mathrm{H}_{2}\right)$ dapat diterima yaitu, budaya organisasi mampu memoderasi pengaruh partisipasi penganggaran terhadap kinerja anggaran pemerintah daerah Kabupaten Badung. Dimana pengaruh yang ditimbulkan akan memperkuat hubungan partisipasi pengganggaran terhadap kinerja anggaran pemerintah daerah Kabupaten Badung.

Budaya organisasi merupakan nilai-nilai dari keyakinan yang dimiliki para anggota organisasi yang dituangkan dalam bentuk norma-norma perilaku para 
ISSN: 2302-8556

E-Jurnal Akuntansi Universitas Udayana

Vol.22.1. Januari (2018): 30-50

individu atau kelompok organisasi ditempat individu tersebut bekerja (Hofstede at.al 1990) dalam Sardjito (2007). Holmes dan Marsden (1996) dalam Sardjito (2007) menyatakan bahwa budaya organisasi mempunyai pengaruh terhadap perilaku, cara kerja dan motivasi para manajer dan bawahannya untuk mencapai kinerja organisasi. Penelitian yang dilakukan oleh Soewito dan Sugiyanto (2001) dalam Sardjito (2007) menunjukkan bahwa budaya berpengaruh signifikan terhadap tercapainya kinerja karyawan yang tinggi. Hasil penelitian yang dilakukan oleh (Masrukhin dan Waridin , 2006) dan (Sitty Yuwalliatin, 2006 dalam Sardjito (2007)) menunjukkan adanya pengaruh positif dari budaya organisasi terhadap kinerja karyawan.

\section{SIMPULAN}

Berdasarkan hasil analisis data dan pembahasan yang telah diuraikan di atas, maka dapat ditarik kesimpulan sebagai berikut partisipasi penganggaran berpengaruh pada kinerja anggaran pemerintah daerah Kabupaten Badung. Budaya organisasi merupakan variabel yang dapat memoderasi pengaruh partisipasi penganggaran terhadap kinerja anggaran pemerintah daerah Kabupaten Badung. Dimana efek moderasi yang diberikan akan memperkuat pengaruh partisipasi penganggaran terhadap kinerja anggaran pemerintah daerah Kabupaten Badung

Saran-saran yang dapat diberikan berkaitan dengan hasil penelitian serta untuk kesempurnaan penelitian selanjutnya yaitu untuk peneliti selanjutnya yang ingin melakukan penelitian serupa, sebaiknya memperluas populasi penelitian. Populasi penelitian tidak hanya diambil pada Satuan Kerja Perangkat Daerah (SKPD) Kabupaten Badung, melainkan bisa dikembangkan pada seluruh kabupaten/kota yang 
ada pada salah satu Provinsi. Penelitian selanjutnya sebaiknya menambahkan satu atau dua variabel bebas atau variabel moderasi agar di dapatkannya penelitian yang kompleks dan luas.

\section{REFERENSI}

Arifin, Solikhun. 2012. "Pengaruh Partisipasi Penyusunan Anggaran terhadap Kinerja Aparat Pemerintah Daerah: Komitmen Organisasi, Budaya Organisasi, dan Gaya Kepemimpinan sebagai Variabel Moderasi". Skripsi S1, UNDIP, Semarang.

Bambang. 1998, "Pengaruh Struktur dan Kultur Organisasional Terhadap Keefektifan Anggaran Partisipatif dalam Peningkatan Kinerja Manajerial: Studi Empiris pada Perusahaan Manufaktur Indonesia”, Jurnal Kelola, No. 18, Vol. VIII, Hal. 61-83.

Brownell, P. 1982. Participation in Budgeting Process: When It Works When It Doesn't. Journal of Accounting Literature. Vol.1: 124-153.

Brownell, P. dan M. McInnes. 1986. "Budgetary Participation, Motivation, and Managerial Performance”. The Acounting Review. Vol. LXI(4). October: 587600 .

Chenhall, R. H. dan Brownell. 1988. "The Effect of Participative Budgeting on Job Statisfaction and Performance Role Ambiguity as an Intervening Variabel. Accounting Organizations aand Sociaty. Vol. 13, Pp. 225-233.

Chen, Clement C. dan Keith T. Jones. 2004. " Budgetary Slack And Performance In Group Participative Budgeting: The Effects Of Individual And Group Performance Feedback And Task Interdependence". in (ed.) Advances in Management Accounting (Advances in Management Accounting, Volume 13) Emerald Group Publishing Limited, pp.183 - 221

Dedi Nordiawan, Ayuningtyas Hertianti. 2010. Akuntansi Sektor Publik. Edisi Kedua: Salemba Empat.

Dian Metta Sari, Luh Putu (2014). "Pengaruh Partisipasi Penyusunan Anggaran terhadap Kinerja Aparat Pemerintah Daerah dengan Kepuasan Kerja dan Komitmen Organisasi sebagai Variabel Moderating (Studi Empiris pada Pemerintah Daerah Kabupaten Badung)”. Skripsi S1, Undiksha Singaraja. 
ISSN: 2302-8556

E-Jurnal Akuntansi Universitas Udayana

Vol.22.1. Januari (2018): 30-50

Frucot, V. dan W. T. Shearon. 1991. "Budgetary Participation, Locus Of Control \& Mexican Managerial Performance And Job Satisfaction”. The Accounting Review. Vol. 65, No. 1, Januari 1991, hal: 80-99.

Ghozali, Imam. 2009. Aplikasi Analisis Multivariate dengan Program SPSS. Edisi Keempat: Penerbit Universitas Diponegoro.

Ikhsan, Arfan \& Muhammad Ishak. 2007. Akuntansi Keperilakuan. Jakarta: Salemba Empat.

Indriantoro, Nur, Bambang Supomo. 2002. Metodologi Penelitian Bisnis untuk Akuntansi \& Manajemen. Edisi Pertama. Yogyakarta: BPFE

Ivancevich John M., Gibson James L., dan Donelly James H., 2000, Organizations, Behavior Structure Processes, Tenth Edition, Irwin McGraw-Hill Companies, USA.

Kenis, I. 1979. "Effect Of Budgetary Goal Characteristics On Managerial Attitudes And Performance". The Accounting Review. Vol. 54, No. 4, Oktober 1979, hal: 707-721.

Kohlmeyer , James M., Sakthi Mahenthiran, Robert J. Parker, dan Terry Sincich . 2014. “ Leadership, Budget Participation, Budgetary Fairness, and Organizational Commitment". in Donna Bobek Schmitt (ed.) Advances in Accounting Behavioral Research (Advances in Accounting Behavioral Research, Volume 17) Emerald Group Publishing Limited, pp.95 - 118

Kurniawan, Muhammad Rizki Nur. 2011. "Pengaruh Komitmen Organisasi, Budaya Organisasi, dan Kepuasan Kerja terhadap Kinerja Organisasi Publik (Studi pada Pemerintah Kabupaten Demak)", Skripsi S1, UNDIP, Semarang.

Leach-Lopez, M.A. W.W.Stammerjohan, dan Mc.Nair, F.M. 2007. Difference in the Role of Job-Relevant Information in The Budget Participation-Performance Relationship among U.S. and Mexican Managers: A Question of Culture or Communication, Journal of Management Accounting Research, Vol.19 pp. 105-136.

Luthans, Fred. 2005.Perilaku Organisasi. Edisi Sepuluh, Diterjemahkan oleh : VivinAndhika Yuwono; Shekar Purwanti; Th.Arie Prabawati; dan Winong Rosari. Yogyakarta: Penerbit Andi.

Mahmudi. 2005. Manajemen Kinerja Sektor Publik. Yogyakarta: UPP AMP YKPN. 
Mahoney, T.A., Jardee dan J. Caroll. 1963. Development of Managerial Performance: A Research Approach. Cincinati, Ohio. Southwestern Publishing, Co.

Mahsun, Muhammad. 2006. Pengukuran Kinerja Sektor Publik. Yogyakarta: BPFE.

Mangkunegara, Anwar Prabu. 2002. Manajemen Sumber Daya Manusia. Bandung: Remaja Rosdakarya.

Mardiasmo. 2002. Akuntansi Sektor Publik. Yogyakarta: Penerbit Andi.

McGill, Ronald. 2001. "Performance Budgeting". International Journal of Public Sector Management. Vol. 14 Iss: 5, pp.376 - 390.

Milani, K. 1975. The Relationship of Participation of Budget Setting to Industrial Supervisor Performance Attitudes: A Field Study. Accounting Review. Hal: 274-284.

Nurlaila. 2010. Manajemen Sumber Daya Manusia I. Jakarta: Penerbit LepKhair.

Otley, D.T. 1978. Budget Use and Managerial Performance. Journal of Accounting Research 16(1): 122-149.

Poerwati, Tjahjaning. 2001. "Pengaruh Partisipasi Penyusunan Anggaran terhadap Kinerja Manajerial: Budaya Organisasi dan Motivasi sebagai Variabel Intervening”. Tesis S2, UNDIP, Semarang.

Prihartini, Ni Luh Gede Candra Maha. 2014. "Pengaruh Partisipasi Penganggaran pada Kinerja Pemerintah Daerah dengan Komitmen Organisasi sebagai Pemoderasi”, Skripsi S1, UNUD, Denpasar.

Priyatno, Duwi. 2011.Buku Saku Analisis Statistik Data SPSS. Yogyakarta: Mediakom.

Purwandani, Trisna. 2012. "Analisis Pengaruh Partisipasi Penyusunan Anggaran terhadap Kinerja Aparat Pemerintah Daerah : Budaya Organisasi dan Komitmen Organisasi sebagai Variabel Moderating(Survey Pada Karyawan Pemda Kabupaten Klaten)", Skripsi S1, UNDIP, Semarang.

Rivai, Vethzal \& Basri. 2005. Performance Appraisal: Sistem yang Tepat untuk Menilai Kinerja Karyawan dan meningkatkan Daya Saing Perusahaan. Jakarta: PT. Raj Grafindo Persada. 
ISSN: 2302-8556

E-Jurnal Akuntansi Universitas Udayana

Vol.22.1. Januari (2018): 30-50

Rynita, Morinda Goestin, Zulfikar. 2005. "Pengaruh Pelimpangan Wewenang terhadap Hubungan Antara Kinerja Manajer dengan Partisipasi dalam Penyusunan Anggaran".Jurnal Akuntansi dan Keuangan Hal. 157-174, Vol. 04, No. 2 September 2005.

Sardjito, Bambang. 2007. "Pengaruh Partisipasi Penyusunan Anggaran Terhadap Kinerja Aparat Pemerintah Daerah: Budaya Organisasi Dan Komitmen Organisasi Sebagai Variabel Moderating", Simposium Nasional Akuntansi X Makassar.

Schein, Edgar H. 2004. Organizational Culture and Leadership. Third Edition. Jossey -Bass Publishers. San Francisco.

Sekaran, Uma. 2006. Metodologi Penelitian untuk Bisnis.Edisi 4, Buku 1, Jakarta: Salemba Empat

Sugiyono. 2014. Metode Penelitian Kuantitatif, Kualitatif, dan Kombinasi (Mixed Methods). Bandung: Alfabeta

Sunyoto, D. 2012. Manajemen Sumber Daya Manusia. Yogyakarta: CAPS.

Supanto. 2014. "Analisis Pengaruh Partisipasi Penganggaran terhadap Budgetary Slack dengan Informasi Asimetri, Motivasi, Budaya Organisasi sebagai Pemoderasi”, Tesis S2,UNDIP, Semarang.

Turnipseed, David L. 1988. "An Integrated, Interactive Model Of Organisational Climate, Culture and Effectiveness". Leadership \& Organization Development Journal. Vol. 9 Iss: 5, pp.17 - 21

Wallace, Joseph, James Hunt, dan Christopher Richards. 1999. "The Relationship Between Organisational Culture, Organisational Climate and Managerial Values". International Journal of Public Sector Management. Vol. 12 Iss: 7, pp.548 - 564

Wati, Eniza. 2008. "Pengaruh Budaya Organisasi Terhadap Hubungan Partisipasi Penyusunan Anggaran Dengan Kinerja Pemerintah Daerah", Skripsi S1, Universitas Negeri Padang.

Wulandari, Nur Endah. 2011. "Pengaruh Partisipasi Penyusunan Anggaran terhadap Kinerja Pemerintah Daerah: Kepuasan Kerja dan Komitmen Organisasi sebagai Variabel Moderating", Skripsi S1, UNDIP, Semarang. 